Holy Harlots 
This page intentionally left blank 


\section{Holy Harlots}

Femininity, Sexuality, and Black Magic in Brazil

\section{Kelly E. Hayes}

\section{甲}

UNIVERSITY OF CALIFORNIA PRESS

Berkeley • Los Angeles • London 
University of California Press, one of the most distinguished university presses in the United States, enriches lives around the world by advancing scholarship in the humanities, social sciences, and natural sciences. Its activities are supported by the UC Press Foundation and by philanthropic contributions from individuals and institutions. For more information, visit www.ucpress.edu.

University of California Press

Berkeley and Los Angeles, California

University of California Press, Ltd.

London, England

(C) 20 I I by The Regents of the University of California

Library of Congress Cataloging-in-Publication Data

Hayes, Kelly E., I968-

Holy harlots : femininity, sexuality, and black magic in Brazil / Kelly E. Hayes.

p. $\mathrm{cm}$.

Includes bibliographical references and index. ISBN 978-0-520-26264-5 (cloth : alk. paper) ISBN 978-0-520-26265-2 (pbk. : alk. paper)

I. Pomba-Gira. 2. Afro-Brazilian cults-Brazil.

3. Brazil-Religious life and customs. I. Title.

BL2590.B7H39 20I I

306.6'996 I 2I I 4098I-dc22

2010046 I 66

Manufactured in the United States of America

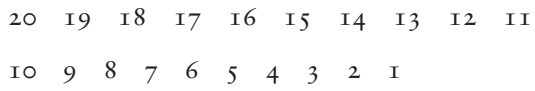

This book is printed on Cascades Enviro Io०, a I0०\% post consumer waste, recycled, de-inked fiber. FSC recycled certified and processed chlorine free. It is acid free, Ecologo certified, and manufactured by BioGas energy. 


\section{To CAC}

Thank you for everything you have ever done, but most of all for bringing me along on this world-record journey of happiness. 
This page intentionally left blank 